\title{
Modification of Antibody Function by Mutagenesis
}

James R. Dasch and Amy L. Dasch

The ability to "fine-tune" recombinant antibodies by mutagenesis separates recombinant antibodies from hybridoma-derived antibodies because the latter are locked with respect to their properties. Recombinant antibodies can be modified to suit the application: Changes in isotype, format (e.g., $s c F v, F a b$, bispecific antibodies), and specificity can be made once the heavy- and light-chain sequences are available. After immunoglobulin heavy and light chains for a particular antibody have been cloned, the binding site—namely, the complementarity determining regions (CDR)—can be manipulated by mutagenesis to obtain antibody variants with improved properties. The method described here is relatively simple, uses commercially available reagents, and is effective. Using the $\mathrm{pComb} 3 \mathrm{H}$ vector, a commercial mutagenesis kit, PfuTurbo polymerase (Agilent), and two mutagenic primers, a library of phage with mutagenized heavy and light CDR3 can be obtained.

It is essential that you consult the appropriate Material Safety Data Sheets and your institution's Environmental Health and Safety Office for proper handling of equipment and hazardous materials used in this protocol.

DNA template

pComb3H is available from Scripps Research Institute, after execution of a Material Transfer agreement (http:// www.scripps.edu/mb/barbas/content/pcomb_images/updatepcomb_image.htm). The sequence of pComb3H is available at GenBank (AY254174).

DpnI and restriction buffer 4 (New England Biolabs)

Escherichia coli XL1-blue cells, electrocompetent (Agilent)

Mutagenic primers:

LCCDR3RAN8: 5' -CTGCAATGTATTTCTGTCAG(NNK) ${ }_{8}$ TTCGGTGCTGGGACCAAGGTG-3' HCCDR3RAN9: 5'-GTCTATTACTGTGCAAGATGG(NNK), TACTGGGGCCAAGGCACCAC-3' where $\mathrm{N}$ is any nucleotide, and $\mathrm{K}=\mathrm{G}$ or $\mathrm{T}$.

Primers are synthesized, 5'-phosphorylated, and purified by polyacrylamide gel electrophoresis.

QuikChange Multi Site-Directed Mutagenesis Kit (Agilent)

This kit contains many of the reagents needed in Step 1.

QIAquick PCR Purification Kit (QIAGEN, \#28104)

This kit contains the elution buffer needed in Step 4.

Water, sterile, nanopure

From the Antibodies collection, edited by Edward A. Greenfield.

(c) 2017 Cold Spring Harbor Laboratory Press

Cite this protocol as Cold Spring Harb Protoc; doi:10.1101/pdb.prot093872 
Equipment

Electroporation device

Microcentrifuge (Beckman Microfuge 9 or equivalent)

Spectrophotometer

Thermal cycler (PerkinElmer model 9600 or equivalent)

Water bath set at $37^{\circ} \mathrm{C}$

This approach was described by Kelley and Momany (2003).

1. Prepare ten $50-\mu \mathrm{L}$ mutagenesis reactions using the QuikChange Multi Site-Directed Mutagenesis Kit:

Reaction buffer (10×)

Water, sterile, nanopure

Double-stranded DNA template (10-100 ng)

Mutagenic primers:

LCCDR3RAN8 (144 ng/ $\mu \mathrm{L})$

HCCDR3RAN9 (151 ng/ $\mu \mathrm{L})$

dNTP mixture

PfuTurbo DNA polymerase (2.5 units/ $\mu \mathrm{L})$

QuikChange Multi enzyme blend
$5 \mu \mathrm{L}$

$35 \mu \mathrm{L}$

$2 \mu \mathrm{L}$

$2 \mu \mathrm{L}$

$2 \mu \mathrm{L}$

$2 \mu \mathrm{L}$

$1 \mu \mathrm{L}$

$1 \mu \mathrm{L}$

2. Perform mutagenesis using the times and temperatures listed below:

\begin{tabular}{lll}
\hline Cycle number & Denaturation & Polymerization \\
\hline 1 & $1 \min$ at $95^{\circ} \mathrm{C}$ & \\
$2-31$ & $1 \min$ at $95^{\circ} \mathrm{C}$ & $1 \min$ at $63^{\circ} \mathrm{C}$ \\
32 & & $8 \min$ at $65^{\circ} \mathrm{C}$ \\
\hline
\end{tabular}

3. Digest the DNA with DpnI as follows:

Mutagenesis reaction (from Step 2)

NEB restriction buffer 4

$50 \mu \mathrm{L}$

DpnI (20 units/ $\mu \mathrm{L})$

$6 \mu \mathrm{L}$

$\mathrm{H}_{2} \mathrm{O}$, distilled

$2 \mu \mathrm{L}$

$2 \mu \mathrm{L}$

Incubate the digest for $1 \mathrm{~h}$ at $37^{\circ} \mathrm{C}$.

4. Purify the digested DNA using a spin column. Elute the DNA from the column with a volume of $30 \mu \mathrm{L}$ of elution buffer.

5. Quantitate the DNA either spectrophotometrically or by comparison to standards using agarose gel electrophoresis.

6. Transform $5 \mu \mathrm{g}$ of DNA from each reaction into $1300 \mu \mathrm{L}$ of electrocompetent E. coli XL1-Blue cells. The final library consists of phage from ten separate transformations.

On a panel of six test antigens, after three rounds of panning, significant numbers of rec Fab could be obtained in each case. The diversity of the library from this relatively simple process is estimated at $1.16 \times 10^{7}$.

\section{RELATED INFORMATION}

A wide number of mutagenic approaches have been described. Many are based on the seminal work of Kunkel (1985) and thus have been referred to as "Kunkel mutagenesis." Several improvements to the Kunkel mutagenesis approach have been described. Huovinen et al. (2012) improved the number of mutant transformants by 300 -fold over the Kunkel method by using rolling circle amplification. 
J.R. Dasch and A.L. Dasch

This work, like many papers in this field, is the subject of an international patent application (PCT/ FI2010/051068). The protocol above was described by Kelley and Momany (2003).

\section{REFERENCES}

Huovinen T, Brockmann EC, Akter S, Perez-Gamarra S, Ylä-Pelto J, Liu Y, Lamminmäki U. 2012. Primer extension mutagenesis powered by selective rolling circle amplification. PLoS One 7: e31817.

Kelley LL, Momany C. 2003. Generation of a phagemid mouse recombinant antibody fragment library by multisite-directed mutagenesis. BioTechniques 35: 750-756.
Kunkel TA. 1985. Rapid and efficient site-specific mutagenesis without phenotypic selection. Proc Natl Acad Sci 82: 488-492. 


\section{Modification of Antibody Function by Mutagenesis}

James R. Dasch and Amy L. Dasch

Cold Spring Harb Protoc; doi: 10.1101/pdb.prot093872

\begin{tabular}{rc}
$\begin{array}{c}\text { Email Alerting } \\
\text { Service }\end{array}$ & Receive free email alerts when new articles cite this article - click here. \\
\hline $\begin{array}{c}\text { Subject } \\
\text { Categories }\end{array}$ & Browse articles on similar topics from Cold Spring Harbor Protocols. \\
& Antibodies (119 articles) \\
& Antibodies, general (289 articles) \\
& Generating Antibodies (71 articles) \\
& Generating Antibodies, general (60 articles) \\
Immunology, general (128 articles) & Mutagenesis (57 articles) \\
& Mutagenesis by PCR (20 articles) \\
& Phage Display (12 articles) \\
& Polymerase Chain Reaction (PCR) (139 articles) \\
\hline
\end{tabular}

